\title{
CLUPEA HARENGUS MEMBRAS: ABOUT THE ETYMOLOGY OF A CERTAIN FISH NAME IN ESTONIAN, LATVIAN AND LIVONIAN
}

\author{
Udo Uibo \\ Institute of the Estonian Language
}

\begin{abstract}
In this article, the names of Clupea harengus membras will be considered in Estonian, (Salaca) Livonian and Latvian (respectively räim, ren'g and renge 'Baltic herring'). It will be shown that the source of all of these words is the Estonian-Swedish strämg (sträng), or its preceding word shape *sträimg. The Latvian renge is borrowed from Estonian-Swedish through Salaca Livonian. Paul Ariste proposed an adequate etymology for the Estonian räim as early as 1933.
\end{abstract}

Keywords: lexicology, etymology, loanwords, Estonian-Swedish dialect, Estonian, Livonian, Latvian

The Baltic herring (in the taxonomy of Linné, Clupea harengus membras) is a small-sized fish, living in the inner parts of the Baltic Sea. In Standard Estonian the word for the fish is räim; in dialects, it is also known as räime or räimes (VMS II: 357). The word has been documented in the literary language since the first Estonian grammar (Stahl 1637: 119 Strömling / Reim; see also: Kikas 2002: 114).

The word räim has, etymologically, been mainly understood as a loanword, based on the Estonian-Swedish dialect word strämg sträng 'strömming, clupea harengus' (Friedenthal, Vendell 1886: 217). The etymology was presented by Paul Ariste in his Master's thesis, which deals with Estonian-Swedish loanwords (Ariste 1933: 99) and it is accepted by most of the researchers of Estonian word origins (Saareste, Raun 1965: 45, with a question-mark, Raun 1982: 147, without a question-mark, Mägiste 2000: 2593, Rätsep 1983: 546, etc.). Being apart from the etymological disquisition's mainstream, there has been an attempt to see the word räim as a form of a substrate speech originating from some type of vanished primal language (e.g. Blesse 1933: 379, Laumane 1973: 190). 
The idea of a form of a substrate speech is probably based on the fact that for Latvians (the southern neighbors of Estonians) the same fish is known as renge. These two words are in some ways similar - they both have a trill, a front vowel and a nasal - but it is phonetically impossible to assume a borrowing from one language to another. In this vague similarity, some scholars tend to rely on an assumption of some primal contacts with unfamiliar languages.

In the Latvian etymological disquisition's mainstream, the word renge 'Baltic herring' is assumed to be a loanword, whose source is either the German Hering 'herring' (Mühlenbachs, Endzelin 1927-1929: 512) or its East Frisian equivalent hereng (Karulis 2001: 749), and the Salaca Livonian ren'g 'Baltic herring' (Kettunen 1938: 333, Winkler and Pajusalu 2009: 165 ) is thought to be borrowed from Latvian. This interpretation presupposes a stressed first syllable's ellipse and an unstressed non-initial syllable's takeover, which would be possible only in exceptional circumstances and is certainly not expected. This is probably one of the reasons why, for Jānis Enzelīns, this etymology is not definite and why he added a question-mark to it.

The origin of the Latvian word does not have an adequate solution because it was borrowed by Latvian from an unusual source. The source of the Latvian renge is the Estonian-Swedish strämg $\sim$ sträng, which (probably from the Swedes on the island of Ruhnu') was borrowed by Salaca Livonian as reńg. In Livonian, the word has lost its word-initial consonant cluster, which is not common among Balto-Finnic languages, and from there it was borrowed without the consonant cluster by Latvian as renge. Phonetically, everything is as expected, so there is actually no need for further comments. Perhaps it should be mentioned that the Latvian renge's second syllable $e$ does not have to be epenthetic. This is indicated by the word shape Renge, written once in 1821 in Salaca Livonian (Winkler and Pajusalu 2009: 165),

1 In fact, the word shape strämg sträng is documented in the 19th century from the Swedes in northwestern Estonia. The same word is documented in the 19th century from the Swedes in Ruhnu as stramm (Vendell 188287: 137), where the final $g$ has already blended into the preceding phone. 
and the fact that in Estonian räim is also an $e$-stem word (Nom. räim, Gen. räime).

However some questions regarding phonetics can arise with the Estonian räim. The word's connection to the EstonianSwedish strämg does not seem to be self-evident, due to the Estonian word's first-syllable diphthong. Estonian räim does not originate from the Estonian-Swedish documented word shape strämg, but from its preceding word shape *sträimg, which in turn developed from the word shape *sträimling. That is derived from the Germanic stem *strauma- 'current, stream'. In the Estonian-Swedish word, a syncope has occurred, and thereby a simplification of the consonant cluster in the derivative's second syllable evolved, as well as a simplification of the diphthong in the first syllable. Because of this, the connection with the derivational base has disappeared. Unlike in the Estonian-Swedish word, the derivation has remained transparent in the Middle Low German word stromelink "ein Fisch: die kleinere Sorte Hering" 'a fish: Herring of a smaller sort' (cf. strōm 'Strom; Strömung, bes. Flut- und Ebbestrom'; see Lübben 1888: 386) and in the Swedish word strömming 'Baltic herring' (cf. ström, 'current, stream'; see Hellquist 1980: 1093).

The Estonian-Swedish word's strämg underlying form *sträim(lin)g reflects the diphthong's *au palatal umlaut $*_{\varepsilon y \text {, }}$ which allegedly evolved after the collapse of the Scandinavian proto-language in the middle of the first millennium. This type of umlaut is distinctive in the Old Norse western dialects (Ralph 2002: 707) and is nowadays shown in the Icelandic and Faeroese languages (the Faeroese streymur 'a flow', Icelandic, Faeroese streyma 'to flow', see Magnússon 1989: 969, 971). However, it is known that many distinctions of the Scandinavian western dialects also occur on the opposite side of the North Germanic linguistic area, being reflected in Old Gutnish and in EstonianSwedish and Finland Swedish dialects. There are a lot of examples of the *au : *y umlaut in the Estonian-Swedish dialect. One of these is the geographical name Reigi in Hiiumaa. Its etymo$\log y$ has been related to the Estonian-Swedish räik (cf. German Rauch, Swedish rök, Icelandic reykur; see Ariste 1935: 11-13), 
which is an equivalent of the Germanic word for smoke (in the figurative sense, also a dwelling or a house).

The fact that Estonian räim does not originate from the Estonian-Swedish documented word shape strämg, but from its predecessor with a diphthong, was clearly stated by Paul Ariste in the phonetic introduction of his Master's thesis: "The situation of these two languages does not let us directly unite Estonian räim and Estonian-Swedish strcem. Keeping in mind the Estonian-Swedish stem word straim, strceum etc. 'ström' $\sim$ isl. Straumr, it has to be assumed that the word's strcemg older shape is *strceim- $(<$ straum-), which fits well with the Estonian equivalent" (Ariste 1933: 23). Unfortunately, the statement was not repeated in the dictionary part of the thesis (cf. Ariste 1933: 23 and 99), and it seems that later researchers failed to note it.

\section{Acknowledgement}

The study was supported by the Estonian Ministry of Education and Research project no SF0050037s10.

\section{Address:}

Udo Uibo

Institute of the Estonian Language

Roosikrantsi 6

Tallinn 10119, Estonia

E-mail: udo@eki.ee

\section{References}

Ariste, Paul (1933) Eesti-rootsi laensõnad eesti keeles. (Acta et Commentationes Universitatis Tartuensis, B 29:3). Tartu.

Ariste, Paul (1935). "Reigi". Eesti Keel 11, 11-13.

Blesse, Ernest (1933) “Laenusuhteist eesti ja läti keele vahel”. Eesti Kirjandus 8, 378-382.

Friedenthal, A. O. and H. A. Vendell (1886) Ordbok öfver estländsk-svenska dialekterna. Helsingfors: Tidnings- \& Tryckeri-aktiebolagets Tryckeri. 
Hellquist, Elof (1980) Svensk etymologisk ordbok. Andra bandet. O-Ö. Malmö: Gleerups.

Karulis, Konstantīns (2001) Latviešu etimologijas vārdnīca. Rīgā: Avots.

Kettunen, Lauri (1938) Livisches Wörterbuch. Helsinki: Suomalais-Ugrilainen Seura.

Kikas, Kristel (2002) "Mida sisaldab Heinrich Stahli Vocabula?". In Tartu Ülikooli eesti keele óppetooli toimetised, 21. Tartu.

Laumane, Benita. (1973) Zīvju nosaukumi latviešu valodā. Rīgā: Zinātne.

Lübben, August (1888) Mittelniederdeutsches Handwörterbuch. NordenLeipzig.

Magnússon, Ásgeir Blöndal (1989) Íslensk orđsifjabók. s. l.: Orđabók Háskólans.

Mägiste, Julius (2000) Estnisches etymologisches Wörterbuch. Bd. VIII. raba-sarm. 2. Aufl. Helsinki: Finnisch-Ugrische Gesellschaft.

Mühlenbachs, K. and J. Endzelin (1927-1929) Lettisch-deutsches Wörterbuch. Bd. III. Riga: Herausgegeben vom lettischen Kulturfonds.

Ralph, Bo (2002) "Phonological and graphematic developments from Ancient Nordic to Old Nordic". In The Nordic languages: an international handbook of the history of the North Germanic languages. Volume I, 703-718. Ed. by Oskar Bandle (main editor), Kurt Braunmüller, Ernst Håkon Jahr, Allan Karker, Hans-Peter Naumann, and Ulf Teleman. Berlin and New York: Walter de Gruyter.

Raun, Alo (1982) Eesti keele etümoloogiline teatmik. Rooma and Toronto: Maarjamaa.

Rätsep, Huno (1983) "Eesti kirjakeele tüvevara päritolu”. Keel ja Kirjandus $10,539-548$.

Saareste, Andrus and Alo Raun (1965) Introduction to Estonian linguistics. Wiesbaden: Otto Harrasowitz.

Stahl, Heinrich (1637) Anführung zu der Esthnischen Sprach. Revall: Chr. Reusner.

Vendell, Herman (1882-1887) Runömålet. Ljud- ock formlära samt ordbok. Stockholm: Kongl. Boktryckeriet.

VMS II = Väike murdesõnastik II. Toimetanud Valdek Pall. Tallinn: Valgus, 1989.

Winkler, Eberhard and Karl Pajusalu (2009) Salis-livisches Wörterbuch. (Linguistica Uralica Supplemantary Series, 3.) Tallinn: Teaduste Akadeemia Kirjastus.

Kokkuvõte. Udo Uibo: Clupea harengus membras: ühe eesti, läti ja liivi kalanime etümoloogiast. Artiklis vaadeldakse Clupea harengus membras'e nimetusi eesti, (Salatsi) liivi ja läti keeles (vastavalt räim, reńǵ, rengge) ja näidatakse, et nende kõigi algallikas on eestirootsi strämg (sträng) või sellele eelnenud sõnakuju *sträimg. Läti 


\section{Udo Uibo}

renge on eestirootsist laenatud liivi keele Salatsi murde vahendusel. Eesti räim'e adekvaatse etümoloogia on esitanud juba Paul Ariste 1933. aastal.

Märksõnad: leksikoloogia, etümoloogia, laensõnad, eestirootsi murre, eesti keel, liivi keel, läti keel 